\title{
Intellectual Capital and Bank Performance in Europe
}

\author{
Gimede Gigante, PhD \\ ${ }^{1}$ Contract Professor of Financial Markets and Institutions, Bocconi University, Italy \\ Correspondence: Gimede Gigante, PhD, Contract Professor of Financial Markets and Institutions, Bocconi \\ University, Italy. E-mail: gimede.gigante@gmail.com
}

Received: April 26, 2012

Accepted: October 27, 2013

Published online: October 30, 2013

doi:10.5430/afr.v2n4p120

URL: http://dx.doi.org/10.5430/afr.v2n4p120

\section{Abstract}

This paper:

- Obtains measures of intellectual capital performance for quoted banks in selected European countries (Czech Republic, Denmark, Finland, Germany, Italy, Norway, Poland, Spain, Sweden) during the 2004-2007 period;

- Investigates empirically the relationship between (i) the efficiency of value creation and (ii) bank market valuation and financial performance;

- Tests the effects of intellectual capital performance on profitability and evaluates whether or not intellectual capital can be considered a decision-making factor for investors.

Using data drawn from public annual reports and Ante Pulic's Value Added Intellectual Coefficient (VAIC) as a measure of the efficiency of capital employed and intellectual capital, the study uses regression models to examine the relationship between corporate value-creation efficiency and a firms' market-to-book value ratios and corporate value-creation efficiency.

Some important findings include:

- The determination of correlation, if any, between the financial performance of the banks and their VAIC.

- The determination of the Italian bank efficiency in the use of intellectual capital in relation to some other European competitors.

- The validation of the assumption as to whether or not investors place higher value on firms with greater intellectual capital.

The research limitations/implications include:

- The failure of the study to consider all banks operating in the countries analyzed (due to insufficient data, mainly for unlisted banks) and the limited time period of three years.

Practical implications of the analysis include:

- The results can assist the managers of the respective banks in benchmarking their positions regarding intellectual capital. The study might also assist policymakers in formulating and implementing policy regarding intellectual capital development, while it may also aid investors in modifying investment strategies.

Keywords: Banking, Financial performance, Intellectual capital, ROAE, ROAA, Value added, Value-creation efficiency

\section{Introduction}

The model discussed herein contrasts the client-product relationship and the relationship between value created and resources employed in the productive process. The correlation between resources and results is what economists usually define as efficiency.

Where:

$$
\mathrm{VA}=\mathrm{OUT}-\mathrm{INP}
$$

$\mathrm{VA}=$ Value Added

OUT $=$ Output

INP = Input. 
The value-added indicator is measured in monetary units (units of value): money earned by an enterprise is what provides value to the enterprise. The indicator is simple, and intellectual capital is one of its central contributing factors.

Using the VAIC and its components, this study aims to investigate the impact of intellectual capital on bank performance through a parametric model.

The measurement of intellectual capital is needed to determine value creation because:

a. A firm's earnings and assets (as reported in financial statements) do not properly determine or describe the company's value. In the differential analysis between book value and market value, there is an additional income flow that is not properly explained by traditional financial methods.

b. Traditional accounting methods for assessing company value are not adequate for knowledge-oriented companies, and therefore cannot represent those elements not solely related to financial and economic performance. Furthermore, these methods do not represent the flows that do not produce immediate earnings but that are extremely important if the company wishes to achieve positive financial results. It is necessary, therefore, to find a way to represent the information contained in the reports concerning external conditions (environmental balance), social factors (social balance) and factors specifically related to competitiveness (intangible balance). In other words, the aim is to make known the intangible drivers that are neglected in financial statements. Despite the role of those intangible drivers in creating value, companies are completely free to include, ignore or discuss them in their voluntary reports.

In 1998, Ante Pulic proposed a coefficient to provide information about value-creation efficiency when determining tangible and intangible assets within a company. The model proposed is an analytical procedure that can be easily used by the relevant stakeholders of a company in order to effectively monitor and evaluate the efficiency of value added (VA) according to a firm's total resources (including intellectual resources) and each major component of these resources:

$$
\text { Value Added = Total Income }- \text { Total Expenses }+ \text { Personnel Expenses }
$$

Labor expense is not calculated into "value added" because of its active role in the value creating process, and is instead considered part of the firm's intellectual potential. Instead of directly valuing the firm's intellectual capital, value added mainly measures the efficiency of the firm's three types of inputs: physical and financial capital (capital employed), human capital and structural capital.

Capital employed efficiency (CEE) is an indicator of value-added efficiency of the capital employed. Human capital efficiency (HCE) is an indicator of value-added efficiency of human capital. Structural capital efficiency (SCE) is an indicator of value-added efficiency of structural capital. CEE and HCE can be viewed as the value added by one monetary unit input of physical assets and human capital, respectively. SCE represents the proportion of total VA accounted for by structural capital. The sum of the three measures results in the coefficient calculated by Pulic: VAIC. The higher a company's VAIC value, the better its value creation potential:

$$
\mathrm{VAIC}=\mathrm{CEE}+\mathrm{HCE}+\mathrm{SCE}
$$

This indicator allows for understanding the overall efficiency of an enterprise, including its intellectual potential. In simple terms, VAIC measures how much new value has been created per monetary unit invested in resources. The benefit of VAIC is that it allows for a standardized and consistent basis of measurement, thereby better facilitating an international comparison using a large, multi-country sample.

\section{Literature on Approaches to Intellectual Capital Measurement}

The measurement of intellectual capital is a crucial aspect of strategic business and marketing management and appears more useful as an internal management tool than as an instrument for external communication to shareholders or investors (Bontis, 2001b). Following is a brief review of the literature concerning efforts over the years to try to describe and measure intellectual capital and its components. An initial distinction is made between internal and external measurement.

\subsection{Internal Measurements of Intellectual Capital}

- Entail component-by-component evaluations;

- Enable management to monitor the company's progress and to take corrective action where and when needed;

- Emphasize flows, trends, and changes; 
- Should be mutually consistent, namely, the methods for measurement should be aligned to reflect common purposes and directions for the company as a whole;

- Have different relevance and usefulness at different company levels.

\subsection{External Measurements of Intellectual Capital}

- Measure the value of intellectual capital in financial terms at the organizational level;

- Describe the company so that it may be assessed by stakeholders, customers and creditors;

- Describe company changes, flows and risk;

- Assess how effectively managers utilize intellectual capital.

The external measurement methods include the following.

\subsubsection{Market Capitalization Approach (MC)}

The approach defines the value of a company's intellectual capital as the difference between the company's market capitalization and its book value, and it considers variables such as:

- Tobin's q [Stewart (1997), Bontis (1998)];

- Market-to-Book Value [Stewart (1997), Luthy (1998)];

2.2.2 Return on Assets Approach (ROA)

The approach defines a company's intellectual capital as the excess return on its tangible assets, and incorporates variables such as:

- $\quad$ Economic Value Added (EVA ${ }^{\mathrm{TM}}$ ) [Stewart (1997)];

- Calculated Intangible Value [Stewart (1997), Luthy (1998)];

- Knowledge Capital Earnings [Lev (1999)];

- Value Added Intellectual Coefficient (VAICTM) [Pulic (1998)];

2.2.3 Direct Intellectual Capital Approach (DIC)

The approach estimates the value of specific, individual intangible assets, and considers the following:

- Technology Broker [Brooking (1996)];

- Citation-Weighted Patents [Bontis (1996)];

- Inclusive Valuation Methodology (IVM) [McPherson (1998)];

- The Value Explorer (TM) [Andriessen \& Tiessen (2000)];

- IA Valuation [Sullivan (2000)];

- Total Value Creation, TVC (TM) [Anderson \& McLean (2000)];

- Accounting for the Future (AFTF) [Nash (1998)];

2.2.4 Scorecard Approach (SC)

The approach generates indicators and indices for identified intangible assets and reports them in scorecards or graphs. It incorporates the following:

- $\quad$ Skandia Navigator (TM) [Edvinsson \& Malone (1997)];

- Value Chain Scoreboard (TM) [Lev (2001)];

- IC-Index (TM) [Roos, Roos, Dragonetti \& Edvinsson (1997)];

- Intangible Asset Monitor [Sveiby (1997)];

- Balanced Score Card [Kaplan \& Norton (1996);

\section{Methodology}

The Value Added Intellectual Coefficient ("VAIC") (Note 1), developed by Ante Pulic, is an analytical tool for measuring the performance of a company (Pulic, 2000; Van der Zahn et al. 2004). It is based on the assumption that measuring and developing a company's value added may have an effect on the company's market value. The connection between value added and market value has also been studied empirically among 250 randomly chosen 
Financial Times Stock Exchange (FTSE) companies and Vienna Stock Exchange companies (see e.g. International Business Efficiency Consulting, 2003; Pulic, 2000). According to the above-mentioned studies, there is a close relationship between the value-creation efficiency of the resources in value creation, i.e. VAIC (Note 2), and the market value of companies.

In particular, VAIC measures a company's total value-creation efficiency. The subordinate concept of VAIC, Intellectual Capital Efficiency (ICE), describes the efficient use of intellectual capital within a company. As already mentioned, the method is based on two resources: capital employed and intellectual capital. Both resources play a significant role in the value of a company and are considered investments. Capital employed is defined as the sum of equity capital, the accumulation of profit-adjusting entries, and liabilities with interest. Intellectual capital consists of human and structural capital (defined in the context of VAIC). The basic premise is that the higher the VAIC and ICE, the better management has utilized the existing potential of the resources employed in creating value (Van deer Zahn et al., 2004).

$\checkmark \quad$ Research Question \# 1: In which manner are banks using their intellectual capital and how can the analysis of intellectual capital help in better understanding the trends in financial performance in the banking sector? (Are banks using intellectual capital to maximize profits, ROAA, ROAE or MVBV?)

$\checkmark \quad$ Research Question \# 2: What does the cross-country analysis within different banking markets reveal?

$\checkmark$ Research Question \# 3: Is it reasonable to consider intellectual capital as a fundamental investment factor?

In order to respond to the questions, we start by examining the relationship between the dependent variables: market/book value (MV/BV), return on average assets (ROAA) and return on average equity (ROAE) and the independent variables: the aggregate measure of intellectual capital (VAIC) and its three major components: SCE, $\mathrm{CEE}$ and $\mathrm{HCE}$. The six linear regression equations are defined as:

$$
\begin{gathered}
\mathrm{M} / \mathrm{B}_{i t}=\alpha_{0}+\alpha_{1} \mathrm{VAIC}_{i t}+\varepsilon_{i t} \\
\mathrm{M} / \mathrm{B}_{i t}=\alpha_{0}+\alpha_{1} \mathrm{CEE}_{i t}+\alpha_{2} \mathrm{HCE}_{i t}++\alpha_{3} \mathrm{SCE}_{i t}+\varepsilon_{i t} \\
\operatorname{ROAA}_{i t}=\alpha_{0}+\alpha_{1} \mathrm{VAIC}_{i t}+\varepsilon_{i t} \\
\mathrm{ROAA}_{i t}=\alpha_{0}+\alpha_{1} \mathrm{CEE}_{i t}+\alpha_{2} \mathrm{HCE}_{i t}++\alpha_{3} \mathrm{SCE}_{i t}+\varepsilon_{i t} \\
\mathrm{ROAE}_{i t}=\alpha_{0}+\alpha_{1} \mathrm{VAIC}_{i t}+\varepsilon_{i t} \\
\mathrm{ROAE}_{i t}=\alpha_{0}+\alpha_{1} \mathrm{CEE}_{i t}+\alpha_{2} \mathrm{HCE}_{i t}++\alpha_{3} \mathrm{SCE}_{i t}+\varepsilon_{i t}
\end{gathered}
$$

The ratio of market value to book value $(\mathrm{M} / \mathrm{B})$ is defined as the market value of the common stock divided by the firm's book value. The market value of the common stock is equal to the number of shares outstanding multiplied by the stock price at year end. In addition to the dependent mark-to-book value indicator, we investigate whether intellectual capital is associated with corporate financial performance and whether it can be a leading indicator of future performance using the dependent variables ROAA and ROAE.

Return on average assets (ROAA) is defined as the return on average assets:

$$
\text { ROAA }=\text { NET INCOME/TOTAL ASSETS x } 100
$$

ROAA is the size-related profitability measure most commonly used in analyzing banks and finance companies. As assets are usually disclosed at the end of reporting periods (years, half years or quarters), the average is an approximation that does not reflect any fluctuation during reporting periods; it is implicitly assumed that fluctuations are fairly smooth.

Return on average equity (ROAE) is defined as the return on average equity:

$$
\text { ROAE }=\text { NET INCOME/AVE EQUITY x } 100
$$

ROAE is an adjusted version of the corporate profitability indicator, return on equity (ROE), in which the denominator, 'shareholders' equity,' is changed to 'average shareholders' equity.' Typically, the return on average equity refers to a company's performance over a fiscal year, so the 'average equity' denominator is usually computed as the sum of the equity value at the beginning and at the end of the year, divided by two. The independent variables in the linear regression models are VAIC and its underlying components: CEE, HCE and SCE.

The VAIC measure and its components were compiled from Bankscope/Amadeus and OSIRIS (source: financial statements). We calculated intellectual capital by using VAIC, and tested the effect of intellectual capital. The data required for the research were obtained from the Bankscope Dataset (for measures of performance) and from 
Datastream. The analysis has been performed with respect to two macro areas: 1) the Italian banking market, and 2) a cross-country analysis worldwide.

\section{Data Analysis}

We analyzed a sample of 64 banks in the European market over the 2004-2007 three-year period. The breakdown by country is presented in Table 1 along with the sample mean values of the bank variables. Across countries, the VAIC analysis shows that Finland has the most efficient use of intellectual capital (VAIC as a mean equal to 12.23). This VAIC greatly outweighs the VAIC averages of the banks from the other countries. German banks (VAIC as a mean equal to 1.88) are those with the lowest level of intellectual capital efficiency. Regarding the efficient use of human capital (HCE), again the Finnish banks rank at the top (HCE as mean equal to 11.20), followed by Czech Republic banks (HCE as a mean equal to 3.40), and the Swedish banks (HCE as a mean equal to 2.98). The German banks also ranked last in terms of $\mathrm{HCE}$ (HCE as a mean equal to 1.40), and were preceded by the Italian banks (HCE as a mean equal to 1.99) and the Spanish banks (HCE as a mean equal to 2.07).

Table 1. Summary of Bank Variables Across Countries

\begin{tabular}{|c|c|c|c|c|c|c|c|}
\hline & MVBV & $\underline{\text { VAIC }}$ & $\underline{\text { ROAA }}$ & $\underline{\text { ROAE }}$ & CEE & $\underline{\mathrm{HCE}}$ & $\underline{\mathrm{SCE}}$ \\
\hline Czech Republic & 2.46 & 4.50 & 1.73 & 19.45 & 0.39 & 3.40 & 0.71 \\
\hline Denmark & 2.08 & 3.41 & 1.86 & 18.58 & 0.40 & 2.44 & 0.57 \\
\hline Finland & 2.04 & 12.23 & 0.80 & 13.32 & 0.39 & 11.20 & 0.64 \\
\hline Germany & 1.82 & 1.88 & 0.20 & 6.37 & 0.25 & 1.40 & 0.24 \\
\hline Italy & 1.69 & 2.85 & 0.92 & 9.82 & 0.32 & 1.99 & 0.53 \\
\hline Norway & 0.96 & 3.58 & 1.07 & 17.46 & 0.36 & 2.53 & 0.59 \\
\hline Poland & 3.31 & 3.01 & 1.68 & 16.82 & 0.40 & 2.11 & 0.50 \\
\hline Spain & 2.39 & 2.74 & 0.88 & 14.07 & 0.26 & 2.07 & 0.40 \\
\hline Sweden & 1.89 & 3.97 & 1.03 & 15.23 & 0.34 & 2.98 & 0.65 \\
\hline
\end{tabular}

Table 2 reports the results of the six regression models on bank performance:

Table 2. Regression Results

\begin{tabular}{lllllll}
\hline Coefficients & $\mathbf{( 1 )}$ & $\mathbf{( 2 )}$ & $\mathbf{( 3 )}$ & $\mathbf{( 4 )}$ & $\mathbf{( 5 )}$ & $\mathbf{( 6 )}$ \\
\hline Intercept & $2.119^{* * *}$ & $1.964^{* * *}$ & $1.010^{* * *}$ & $0.455^{*}$ & $12.293^{* * *}$ & $6.184^{*}$ \\
& $(0.104)$ & $(0.227)$ & 0.097 & $(0.197)$ & $(1.018)$ & $(1.881)$ \\
VAIC & -0.030 & & $0.036^{*}$ & & $0.471^{*}$ & \\
& $(0.022)$ & & 0.021 & & $(0.217)$ & \\
CEE & & 0.256 & & $2.061^{* * *}$ & & $27.607^{* * *}$ \\
& & $(0.496)$ & & $(0.430)$ & & $(4.106)$ \\
HCE & & -0.033 & & $0.040^{*}$ & & $0.694^{* * *}$ \\
& & $(0.0235)$ & & $(0.020)$ & $(0.194)$ \\
SCE & & 0.101 & & -0.228 & & $-6.464^{* * *}$ \\
& & $(0.228)$ & & $(0.198)$ & & $(1.884)$ \\
\hline
\end{tabular}

Note: Numbers in parentheses represent standard errors of the coefficient estimates.

*** Indicates the estimated coefficient is statistically significant at the 0.0001 significance level.

** Indicates the estimated coefficient is statistically significant at the 0.001 significance level.

* Indicates the estimated coefficient is statistically significant at the 0.01 significance level. 
The MV/BV regression equation (3) shows that the VAIC is slightly negative. The adjusted $\mathrm{R}^{2}$ is 0.01 indicating that about $1 \%$ of the variation in MV/BV can be explained by the variations in the VAIC independent variable. The $\mathrm{MV} / \mathrm{BV}$ regression equation (4) yields similar results. VAIC and its underlying components do not seem to provide definitive explanations for changes in MV/BV in the selected sample data for the banks.

The ROAA regression equation (5) and the ROAE regression equation (7) provide more statistically significant results on the VAIC estimates. Both coefficients are positive and statistically significant. At 0.471, the ROAE regression equation (7) coefficient is more statistically significant, indicating that for a one unit increase in VAIC, ROAE increases $0.47 \%$ on the average, with all other variables kept constant.

The ROAA regression equation (6) and the ROAE regression equation (8) seem to provide the best linear model fits of the two dependent bank variables. The individual components of VAIC in the two equations provide a better explanation of the variation in ROAA and ROAE. The coefficient estimates for CEE and HCE are positive and statistically significant in both models. The coefficient estimate for SCE is negative in both models and statistically significant in equation (8). In terms of the overall goodness-of-fit test, equations (6) and (8) yield much higher adjusted $\mathrm{R}^{2}$ measures at 0.14 and 0.29 , respectively.

\section{Conclusions}

Intellectual capital management is not and cannot be a means to an end in and of itself, but rather it can be a function of value creation, which is an important goal of any business. Therefore, it is inevitable that any discussion of intellectual capital must also consider the concept of value creation. The VAIC method is a practical means of doing research on it. In the short term, a correlation between intellectual capital and market value has not been found, however, a correlation has been found between intellectual capital and the financial performance of some companies.

Modern theory defines business activity as value added and wealth. Creating value added and wealth necessitates earnings and thus, the enhancement of customer relationships and the realization that the tangible form of value creation (income, value added) must also be linked over the long term to intangible forms of value creation (increased time and effectiveness of communication, better relationships with customers, building and maintaining a good reputation). The key to a firm's success lies in creating cause-and-effect relationships between these two forms of value creation. It can be argued that one of a manager's main challenges is the creation of conditions that will allow for a successful generation of intangible value (knowledge, services, experience, benefits, speed, quality, and image) and its subsequent transformation into tangible value (income, profit, value added, shares, and market value). Systematic value-creation management is based on the premise that this concept is firmly embedded in the company as the ultimate business goal. This orientation towards value creation is a long-term strategy, which by no means includes increasing profits over the short term. Its objective is strictly to improve the ability of a company to create value over the long term, which we believe includes investments in intellectual capital. Throughout this process, it is necessary to analyze and improve the value-added chain. The logic of value creation is relevant for both individual banks and national banking systems. Therefore, the central regulatory system for each country should develop a stronger focus on value creation and issues related to intellectual capital if it wants to optimize the use of intellectual resources.

\subsection{Findings}

We conclude this work with a summary of answers to the research questions posed as the outset.

\section{$\checkmark$ Research Question \# 1: In which manner are banks using their intellectual capital and how can the analysis of intellectual capital help in better understanding the trends in financial performance in the banking sector?? In other words, are banks using IC to maximize profits, ROAA, ROAE or MVBV?}

With reference to the banks analyzed for this study, an increasing correlation was noted between investments in intellectual capital and profit levels. However, the ROAA and ROAE indicators for these banks reflected very different levels of value added. This means that little value was actually really created in certain cases, at least from a short-term perspective, even though financial performance substantially increased.

\section{$\checkmark \quad$ Research Question \# 2: What does the cross-country analysis within different banking markets reveal?}

The cross-country analysis within different banking markets reveals that Italian banks are generally less efficient in the use of intellectual capital than are Spanish and northern European banks. German banks (as a mean) are positioned just a level below the Italian banks, but they are better performers than the Eastern European banks (except for those from Bulgaria). The mean VAIC for Bulgaria, Czech Republic, and Poland is inferior to that registered for Sweden, 
Norway, Finland, and Denmark. Mediobanca, in Italy, had the highest level of intellectual capital capacity (the mean of the VAIC for three years is 6.8).

\section{$\checkmark$ Research Question \# 3: Is it reasonable to consider intellectual capital as a fundamental investment factor?}

This study has attempted to provide empirical evidence to support assumptions about the relationship between intellectual capital and some financial performance. However, the results partially support the hypothesis of the regression analysis in equations (6) and (8). The evidence cannot be considered significant in the other equations.

\subsection{Strengths of the Study}

The analysis in this paper (at a local, but also an international level) could help the managers of the respective banks in determining their positions regarding intellectual capital. It might also assist policymakers in formulating and implementing intellectual capital-development plans. Additionally, the analysis might be able to aid investors in modifying investment strategies, while also allowing banks to benchmark themselves in order to improve their value creation capabilities.

The regression analysis results provide some empirical evidence of how investors could place a higher value on firms with better intellectual capital efficiency, yielding greater profitability. For sure, they highlight the importance of studying intellectual capital to enhance a firm's profitability, maybe from a longer term perspective.

Using VAIC as the principal model in this study provides several benefits (apart from the benefit of being able to decipher the value added efficiency of country banking systems and intellectual capital resources).

First, VAIC allows for a standardized and consistent basis of measurement, making it possible to conduct an international comparative analysis more effectively when using a large sample size and spanning across various industrial sectors. Alternative methods for measuring intellectual capital are limited for measuring intellectual capital consistently across a large and diversified sample for comparative analysis.

Second, all data used in the VAIC calculation are based on audited information. Therefore, such calculations can be considered objective and verifiable (other methods for measuring intellectual capital have been criticized for the subjectivity of their underlying indicators). Additionally, concerns have been raised about difficulties in verifying information used in calculating indicators serving as the basis for other methods to measure intellectual capital.

Third, VAIC is a straightforward equation, that meaning various internal and external stakeholders can easily calculate it. Alternative methods for measuring intellectual capital are limited as they can only be calculated by internal parties within companies or they rely upon sophisticated models, analysis and principles.

\subsection{Limitations of the Study}

For the purposes of this paper, we tested the performance intellectual capital over a limited number of banks and thus without considering the banking systems of the countries analyzed in their entirety. In addition, the study is based on three years of data only and thus it considers a short-term perspective only.

We suggest that any works to extend this study use a more representative base and, more importantly, have a longer time horizon. They should consider either periods before and/or after 2004-2007 in order to make a comprehensive study based on a divided timeline, to analyze the effects of investment in intellectual capital on market value creation over the longer term, and to gain more representative econometric explanations of the assumptions.

\section{References}

Andersen R. \& McLean R. (2000). Accounting for the Creation of Value. Ongoing research project sponsored by the Canadian Institute of Chartered Accountants.

Andriessen, D. and Tissen, R. (2000). Weightless Wealth: Find Your Real Value in a Future of Intangible Assets. London, United Kingdom: Financial Times Prentice-Hall.

Bontis, N. (1996). There's a price on your head: managing intellectual capital strategically.

Bontis, N. (1998). Intellectual capital: an exploratory study that develops measures and models. Management Decision, 36/2, pp. 63-76. http://dx.doi.org/10.1108/00251749810204142

Bontis, N., William, C. C. L., \& Richardson, R. (2000). Intellectual capital and business performance in Malaysian industries. Journal of Intellectual Capital, 1(1), 85-100. http://dx.doi.org/10.1108/14691930010324188

Brooking, A. (1996). Intellectual Capital: Core Assets for the Third Millennium Enterprise. London, United Kingdom: Thomson Business Press. 
Brummet, R. L., Flamholtz, E. G., \& Pyle, W. C. (1968). Human Resource Measurement: A Challenge for Accountants. The Accounting Review, April, 217-224.

Chen, M. C., Cheng, S. J., \& Hwang, Y. (2005). An empirical investigation of the relationship between intellectual capital and firms' market value and financial performance. Journal of Intellectual Capital, 6(2), 159-176. http://dx.doi.org/10.1108/14691930510592771

Choo, C.W. and Nick Bontis. (2002). The Strategic Management of Intellectual Capital and Organizational Knowledge. New York, NY: Oxford University Press.

Cooper, D. R., \& Schindler, P. S. (2003). Business Research Methods, (8th ed.). Boston, MA: Erwin McGraw-Hill.

Edvinsson \& Malone (1997): Intellectual Capital - Realizing your company's true value by finding its hidden brainpower. New York, NY: Harper Collins.

Firer, S., \& Williams, S. M. (2003). Intellectual capital and traditional measures of corporate performance. Journal of Intellectual Capital, 4(3), 348-360. http://dx.doi.org/10.1108/14691930310487806

Gigante G., \& Previati D. (2011). A Knowledge Oriented Approach To The Investigation Of Banking System Performances, International Journal of Economics and Finance.

Kaplan, R. S., \& Norton, D. P. (1996). The Balanced Score-card: Translating Strategy into Action. Boston, MA: Harvard Business School Press.

Kaplan, R. S., \& Norton, D. P. (2004). Strategy Maps. Converting Intangible Assets into Tangible Outcomes. Boston, MA: Harvard Business School Press.

Lev, B., \& Radhakrishnan, S. (2003). The measurement of firm-specific organization capital. NBER Working Paper, No. 9581., Retrieved from http://www.nber.org/papers/w9581.htm

Lev, B. (2001). Intangibles-management-measuring and reporting. New York, NY: Brookings Institution Press.

Luthy, D. H. (1998). Intellectual Capital and its Measurement. Paper presented at the Proceedings of the Asian Pacific Interdisciplinary Research in Accounting Conference (APIRA), Osaka, Japan.

McPherson, M., Arango, P., Fox, H., Lauver, C., McManus, M., Newacheck, P.W., Perrin, J.M., Shonkoff, J.P., \& Strickland, B. (1998). A new definition of Children with Special Health Care Needs. Pediatrics. http://dx.doi.org/10.1542/peds.102.1.137

Morse, W. J. (1973). A Note on the Relationship Between Human Assets and Human Capital. The Accounting Review, July, 589-593.

Nash, H.H. (1998), "Accounting for the future", Prospective Accounting Initiative. Retrieved from http://home.sprintmail.com/, humphreynash/indexback.htm.

Pakes, A. (1985). On patents, R\&D and the stock market rate of return. Journal of Political Economy, 93, 390-409. http://dx.doi.org/10.1086/261305

Previati, D. \& Vezzani, P. (2007). Il Capitale intellettuale: misurazione, gestione e valorizzazione. Prospettive di analisi e prassi manageriali per il settore dei servizi finanziari, Rome, Italy: Bancaria Editrice.

Pulic, A. (1998). Measuring the performance of intellectual potential in knowledge economy, Retrieved from www.vaic-on.net (accessed 30 June 2004), .

Pulic, A. (1998). Measuring the performance of intellectual potential in knowledge economy. Retrieved from http://www.measuring-ip.at/Opapers/Pulic/Vaictxt.vaictxt.html

Pulic, A. (2000). An accounting tool for IC management. Retrieved from http://www.vaic-on.net/

Pulic, A. (1997), The physical and intellectual capital of Austrian banks. Retrieved from http://irc.mcmaster.ca (accessed 11 June 2004).

Pulic, A. (2000b). MVA and VAIC analysis of randomly selected companies from FTSE 250. Retrieved from http://www.vaic-on.net/downloads/ftse30.pdf

Pulic, A. (2001). Value-creation efficiency analysis of Croatian banks 1996-2000. Retrieved from www.vaic-on.net

Roos, G., Roos, J., Edvinsson, L., \& Dragonetti, N. C. (1997). Intellectual Capital Navigating in the New Business Landscape. New York, NY: New York University Press. 
Skandia Insurance Company (1995-2000). Visualizing Intellectual Capital in Skandia. Supplement to Skandia Annual Reports 1994.

Stewart, G. B. (1991). The Quest for value: the EVATM Management Guide. Philadelphia, PA: HarperCollins.

Stewart, K. E. (1997). The New Wealth of Organizations. New York, NY: Doubleday/Currency.

Sullivan P. (2000). Value-driven Intellectual Capital. How to convert intangible corporate assets into market value. Toronto, Ontario: Wiley Canada.

Sveiby KE (1997a): The Intangible Assets Monitor, Journal of Human Resource Costing \& Accounting Vol 2, Number 1, Spring 1997. http://dx.doi.org/10.1108/eb029036

Williams, M. (2001). Is intellectual capital performance and disclosure practices related? Journal of Intellectual Capital, 2(3), 192-203. http://dx.doi.org/10.1108/14691930110399932

\section{Appendix}

\section{Value Added}

Value added (VA) is calculated as the difference between output and input. The basic definition is:

Value Added = Output - Input, where Output is defined as the gross income of the firm and Input is defined as the operating expenses of the firm excluding labor costs.

Value Added can also be calculated from the banks' financial statements:

$$
\begin{gathered}
\mathrm{VA}=\text { Total Operating Income }(\mathrm{TOI})-\text { Total Operating Expense }(\mathrm{TOE})+\text { Personnel Expenses }(\mathrm{PE}) \\
\text { TOI }=\text { Interest Income }- \text { Interest Expense }=\text { Net Interest Revenue } \\
+ \text { Net Commission Revenue }+ \text { Net Trading Revenue }+ \text { Other Operating Income } \\
\text { TOE }=\text { Personnel Expenses }+ \text { Other Administrative Expenses }+ \\
\text { Other Operating Expenses }+ \text { Loan Loss Provisions }
\end{gathered}
$$

VAIC

$$
\begin{gathered}
\mathrm{VAIC}=\mathrm{HCE}+\mathrm{CEE}+\mathrm{SCE}(\text { Value Added Intellectual Coefficient) } \\
\mathrm{HCE}=\mathrm{VA} \div \mathrm{HC} \text { (Indicator of human capital efficiency) } \\
\mathrm{CEE}=\mathrm{VA} \div \mathrm{CE} \text { (Indicator of capital employed efficiency) } \\
\mathrm{SCE}=\mathrm{SC} \div \mathrm{VA} \text { (Indicator of structural capital efficiency) }
\end{gathered}
$$

Where:

$\mathrm{HC}=$ Personnel Cost (viewed as an investment);

$\mathrm{CE}=$ Capital Employed (both physical and financial capital).

$$
\begin{gathered}
\mathrm{SC}=\mathrm{VA}-\mathrm{HC} \text { (an appropriate proxy for structural capital } \\
\text { and result of human capital's past performance) }
\end{gathered}
$$

Structural Capital, as the second component of intellectual capital, is calculated as:

$$
\mathrm{SC}=\mathrm{VA}-\mathrm{HC}
$$

Where:

$\mathrm{SC}=$ structural capital for company;

$\mathrm{VA}=$ value added;

$\mathrm{HC}=$ total salaries and wages.

As the equation already indicates, this form of capital is not an independent aggregate, as is human capital. It is dependent on the created value added and in reverse proportion to HC. This means that the bigger the share of human capital (HC) in the created value added (VA), the smaller the share of structural capital (SC). In some cases, SC is not present (e.g. if VA is less than the investments in HC). Because they must correspond to VA, the efficiencies of $\mathrm{HC}$ and $\mathrm{SC}$ are calculated in a different manner. If SC were calculated in the same way as $\mathrm{HC}(\mathrm{VA} / \mathrm{SC})$, the 
efficiency of SC would rise as $\mathrm{HC}$ efficiency decreases, which is impossible. On the contrary, as the efficiencies of $\mathrm{HC}$ and $\mathrm{SC}$ rise, the total efficiency of intellectual capital increases.

Structural Capital Efficiency (SCE) is therefore calculated as:

$$
\mathrm{SCE}=\mathrm{SC} / \mathrm{VA}
$$

Where:

$\mathrm{SCE}=$ structural capital efficiency (for the company);

$\mathrm{SC}=$ structural capital;

$\mathrm{VA}=$ value added.

Intellectual Capital Efficiency (ICE) is obtained by adding up the partial efficiencies of human and structural capital:

$$
\mathrm{ICE}=\mathrm{HCE}+\mathrm{SCE}
$$

Where:

ICE = intellectual capital efficiency coefficient;

$\mathrm{HCE}=$ human capital efficiency coefficient;

$\mathrm{SCE}=$ structural capital efficiency coefficient.

\section{Notes}

Note 1. VAIC TM (Value Added Intellectual Capital) - Introduced to an international audience in Canada at the Third Intellectual Capital World Congress during a presentation by the "Austrian Team for Intellectual Potential", verified in 2001 as relevant intellectual capital tool through the article by M. Williams who won the best paper award in that occasion.

Note 2. The model has inspired articles published, amongst others, in the Journal of Technology, the Global Business \& Economy Review, the Journal of Business Excellence," and the Journal of Intellectual Capital. 